\title{
EFEKTIFITAS PEMANFAATAN SUMBER BELAJAR BERBASIS MULTIMEDIA DI SEKOLAH MINGGU BNKP
}

\author{
Senida Harefa \\ Institut Agama Kristen Negeri Tarutung \\ Email: senida.harefa@gmail.com
}

\begin{abstract}
Abstrak: Penelitian ini bertujuan untuk mengetahui Efektifitas Pemanfaatan Sumber Belajar Berbasis Multimedia Pada Pembelajaran Sekolah Minggu BNKP dengan menggunakan Metode penelitian adalah Penelitian Pengembangan, dengan jumlah Populasi 30 Orang dan Sampel 25 Orang anak Sekolah Minggu dan 5 Orang Guru Sekolah Minggu, menggunakan Instrumen Penelitian Angket, Teknik analisa data deskriptif persentase.Hasil pengujian hipotesis menunjukkan bahwa Efektifitas Pemanfaatan Sumber Belajar Berbasis Multimedia Dalam Pembelajaran Sekolah Minggu BNKP lebih tinggi dari $80 \%$ dari Kriteria yang diharapkan. Disimpulkan bahwa Efektifitas Pemanfaatan Sumber Belajar Berbasis Multimedia Dalam Pembelajaran Sekolah Minggu BNKP mencapai Rata-rata: 95\% (kriteria Sangat Baik)
\end{abstract}

Kata Kunci: Efektifitas, Sumber Belajar, Multimedia, Sekolah Minggu

\section{PENDAHULUAN}

Pengajaran Sekolah Minggu di gereja BNKP tidak memiliki kurikulum tetap, dan juga tidak memiliki buku panduan yang diterbitkan oleh Gereja seperti gereja-gereja lain, selain Alkitab dan ayat Firman Tuhan yang ditetapkan BPHMS (Badan Pekerja Harian Majelis Sinode) BNKP dalam perikopen. Materi diambil dari Alkitab dan diajarkan kepada anak-anak jemaat dengan usia bervariasi dari balita hingga remaja usia 14 tahun. Penyampaian pengajaran dengan menggunakan komunikasi secara verbal.

Penyampaian materi yang bersumber dari Alkitab dan contoh-contoh kehidupan keseharian bukanlah hal yang mudah. Tidak sedikit guru-guru sekolah minggu mengeluh karena kesulitan sumber belajar, bahan ajar maupun alat peraga dalam pembelajaran Sekolah Minggu. Kurangnya sumber belajar bahan ajar dan alat peraga tersebut berdampak pada ketidak hadiran anak di Sekolah Minggu karena dirasa pembelajaran di Sekolah Minggu kurang menarik sehingga Guru Sekolah Minggu juga sering mengeluh karena mengalami krisis murid Sekolah Minggu. Siapakah yang paling bertanggung jawab dalam memperkenalkan Yesus Kristus kepada anak dan memberi dukungan yang dibutuhkan dalam perkembangan iman kristiani anak-anak? Ada sebagian orang mengatakan bahwa orangtualah yang bertanggung jawab untuk memperkenalkan Yesus kepada anakanaknya dan sebagian lagi menjawab bahwa guru Sekolah Minggulah yang bertanggung jawab untuk memperkenalkan Yesus kepada anakanak. Kedua pemahaman tersebut adalah benar, bahwa kenyataannya gereja dengan dukungan para orang tua anak telah mengadakan berbagai kegiatan pembinaan yang tujuan utamanya menolong anakanak. “.......Sekolah Minggu berfungsi untuk menginjili Laki-laki, perempuan, 
kaum muda, orang dewasa, dalam sejarah Sekolah Minggu menemukan Yesus sebagai juruselamat melalui pelayanan dari guru-guru yang setia. Ini berarti bahwa Sekolah Minggupun salah satu wadah yang tidak kalah penting dalam mendukung iman kristiani anak-anak. (Kristianto 2008:135) Oleh sebab itu kegiatan Sekolah Minggu harus diupayakan menarik agar anak-anak termotivasi untuk selalu hadir. Melalui pembelajaran Sekolah minggu akhlak atau karakter/ tingkah laku anak dapat terbentuk menjadi baik, karena di Sekolah Minggu anak diajak untuk berbuat baik.

Di zaman teknologi sekarang ini anak-anak pada umumnya lebih senang menonton televisi di rumah dari pada datang ke Sekolah Minggu. Dirumah mereka menghabiskan waktu menonton TV dengan tontonan film kartun seperti Upin-Ipin, Sponge Bob, Naruto, sinetron dan hiburan lain yang menyenangkan hati mereka. Hal ini seakan mengisyaratkan bahwa acara TV lebih menarik daripada acara Sekolah Minggu.

Untuk menyikapi hal ini maka Acara Sekolah Minggu pun harus bersaing keras dengan dunia hiburan anak-anak masa kini, baik yang ditayangkan melalui TV maupun lewat berbagai media yang tersedia dengan para tokohnya yang sangat memikat hati anak-anak. "Kesalahan yang sering terjadi di Sekolah Minggu adalah kebanyakan para pengajar $90 \%$ lebih suka menggunakan komunikasi verbal (berbicara), sedangkan anak-anak Sekolah Minggu lebih suka $90 \%$ di ajar menggunakan komunikasi yang melibatkan body kinestetik (gerakan tubuh). (Siswanto 2014:4) Dalam hal ini, guru Sekolah Minggu dituntut mengajarkan Alkitab secara kreatif, mengupayakan agar setiap acara Sekolah Minggu selalu melibatkan an anak-anak untuk selalu aktif. Dengan demikian Sekolah Minggu menjadi acara yang dinamis, kreatif dan sesuai dengan dunia anak masa kini. Dengan kata lain para guru sekolah minggu diharapkan dapat membangun sebuah Sekolah Minggu yang maju dan berkembang, baik dalam segi kualitas maupun kuantitas.

Salah satu pendekatan untuk mewujudkan misi di atas adalah "menggunakan teknologi untuk mengubah suasana pembelajaran dari pasif menjadi aktif, serta student friendly". (Felder \& Brent, 2001).Hal ini berarti bahwa sumber belajar yang menarik dan partisipasi anak untuk terlibat aktif dalam pembelajaran perlu dibangun contohnya dengan penggunaan sarana teknologi informasi komputer, Proyektor beserta aplikasi pendidikan berupa animasi pembelajaran, CD interaktif, tape recorder, DVD player dan televisi beserta pemanfaatan internet sebagai sumber belajar yang mendorong anak-anak mengembangkan kemampuan mencari informasi sehingga guru dapat terbantu dalam mencapai tujuan pembelajaran.

Sarana teknologi informasi tersebut di atas disebut Multimedia. Multimedia adalah "alat, media dan pendekatan yang digunakan untuk membuat komunikasi diantara guru dengan peserta didik selama proses pembelajaran menjadi lebih berkesan". Munir (2001:15).

Media dan teknologi supaya penggunaannya dapat memberikan kontribusi sesuai yang diharapkan terhadap kualitas hasil belajar, maka penggunaan media dan teknologi diintegrasikan dengan kegiatan belajar anak-anak.

Sumber belajar juga dapat didefinisikan sebagai bahan-bahan atau materi pelajaran yang disusun secara 
sistematis yang digunakan oleh guru dan anak didik dalam proses pembelajaran, menuntut kemampuan seorang guru untuk melakukan proses pembelajaran yang dapat meningkatkan kreatifitas, daya tarik kepada anak-anak sehingga pembelajaran dapat tercapai secara optimal. Dalam hal ini kreatifitas guru sangat diperlukan.

Di era teknologi informasi dan komunikasi saat ini sangat dimungkinkan untuk memanfaatkan sumber belajar pada pembelajaran anak Sekolah Minggu dalam format digital yang interaktif dengan fasilitas dukungan multimedia. Pengajaran dan Media Pembelajaran merupakan satu kesatuan yang tidak dapat dipisahkan dari sejarah kehidupan manusia. Secara sederhana, pengajaran dapat diartikan sebagai sebuah proses belajar mengajar yang memberikan dan menghasilkan pengetahuan dan keahlian. Dalam setiap proses mengajar, selalu diperlukan alat atau benda, sebagai sarana untuk menyampaikan pesan, yang kemudian lazim disebut dengan media pembelajaran. Menurut Thorndike, belajar adalah proses interaksi antara stimulus dan respon. Stimulus adalah apa yang merangsang terjadinya kegiatan belajar dapat berupa alat, media dan sumber belajar Sedangkan respon adalah reaksi yang dimunculkan peserta didik ketika belajar. Diketahui bahwa "komputer sebagai alat elektronik yang termasuk kategori multi media mampu melibatkan berbagai indera dan organ tubuh, seperti: telinga (audio), mata (visual), dan tangan (kinetik) yang dengan libatannya dalam pembelajaran memungkinkan informasi atau pesan yang disampaikannya mudah dimengerti" (Munadi, 2012:148). Maka dapatdipahami bahwa kegiatan belajar lebih efektif apabila dilaksanaakan dengan menggunakan alat/media sehingga menimbulkan respon dari diri siswa. Berdasarkan penjelasan di atas penulis melakukan penelitian untuk tujuan menilai dan mendapatkan data tentang Efektifitas Pemanfaatan Sumber Belajar Berbasis Multimedia Dalam Pembelajaran Sekolah Minggu.

Multi media menurut Asyhar, (2012:75) merupakan penggabungan dua kata "multi" dan "media" . Multi yang berarti "banyak " sedangkan media bentuk jamaknya berarti medium". Sajian multimedia berbasis komputer dapat diartikan sebagai teknologi yang mengoptimalkan fungsi komputer sebagai sarana untuk menampilkan dan merekayasa teks, grafik, gambar animasi, suara dan video dalam sebuah tampilan yang terintegrasi.

Teks merupakan bentuk media yang paling umum digunakan dalam menyajikan informasi serta dapat disajikan dengan berbagai bentuk font. Gambar atau grafik berarti still image seperti foto dan gambar. Manusia sangat berorientasi pada penglihatan (visual-oriented), dan gambar merupakan sarana yang sangat baik untuk menyajikan informasi. Penyajian suara merupakan cara lain untuk memperjelas pengertian suatu informasi. Suara dapat lebih menjelaskan karakteristik suatu gambar. Animasi dapat diartikan sebagai sebuah objek yang bergerak dinamis. Animasi adalah proses penciptaan efek gerak atau efek perubahan bentuk yang terjadi selama beberapa waktu. Video adalah teknologi untuk menangkap, merekam dan memproses, mentransmisikan dan menata ulang gambar dan gerak. Video sangat erat kaitannya dengan motion dan sound.

Dari multimedia guru dapat membuat presentasi mengembangkan materi pembelajaran terutama membaca dan mendengarkan secara mudah. Pertama, pada pengembangan materi pembelajaran untuk dibaca, program aplikasi presentasi dapat dibuat guru 
dengan cara memasukkan teks dalam slide pertama, Kedua, pada pengembangan materi pembelajaran untuk didengar, guru dapat membuat bahan pelajaran dengan video atau audio. (Munadi, 2012:150-151). Sodikin, dkk (2009:742) menerangkan Multimedia interaktif adalah suatu multimedia yang dilengkapi dengan alat pengontrol yang dapat dioperasionalkan oleh pengguna, sehingga pengguna dapat memilih apa yang dikehendaki untuk proses selanjutnya. Menurut Asyhar (2012: 186) Program Powerpoint salah satu software yang dirancang khusus untuk mampu menampilkan program multimedia dengan menarik, mudah dalam pembuatan, mudah dalam penggunaan, dan relative murah, karena tidak membutuhkan bahan baku selain alat untuk penyimpanan data ( data stroge).

Dari penjelasan di atas maka dapat disimpulkan bahwa pengembangan sumber belajar berbasis multimedia bukan hal yang sulit dan sangat besar peranannya dalam pencapaian tujuan pembelajaran. Selain menarik, penggunaan multimedia banyak membantu guru dalam membelajarkan anak didiknya.

Penggunaan Multimedia dalam pembelajaran anak Sekolah Minggu yang berumur 11 tahun ke bawah sangatlah tepat. Hal ini didasari dari pendapat para ahli psikologi yakni Piaget dikutip Sumanto (1990:126) bahwa taraf berpikir anak berada pada tingkat operasi konkrit. Sejalan dengan hal tersebut Kadarmanto (2005:121) mengemukakan "anak belajar semakin efektif kalau tidak hanya mendengar saja, tetapi ia juga melihat, dan akan semakin efektif lagi bila ia mendengar melihat dan turut aktif ambil bagian di dalamnya" dari kedua pendapat di atas dapat disimpulkan bahwa untuk memahami suatu konsep, anak masih harus diberikan kegiatan yang berhubungan dengan benda nyata atau kejadian nyata yang dapat diterima akal mereka. Kehadiran multimedia dalam pembelajaran tidak hanya membantu guru membelajarkan anak didiknya melainkan hampir bisa menggantikan guru mengajar di depan kelas karena dapat dirancang sebagai "guru bantu" untuk pelaksanaan pembelajaran melalui media teks, audio, video dan animasi yang terpadu dan dikemas dalam suatu paket media interaktif berbasis komputer sehingga pemanfaatan sumber belajar berbasis multimedia dapat mengefektifkan pembelajaran.

Pemanfaatan sumber belajar berbasis multimedia dalam pembelajaran sekolah minggu dikatakan efektif bila 1). Menciptakan suasana ingin tahu yang bergairah. 2) Membantu guru memperjelas ide-ide dan kata-kata, 3)Mempermudah anak belajar lebih efektif. Manusia hanya dapat mengingat $20 \%$ dari apa yang dibaca, 30\% dari apa yang didengar, $40 \%$ dari apa yang dilihat dan 50\% dari apa yang dikatakan dan $60 \%$ dari apa yang dikerjakan. Kemampuan anak untuk mengingat sampai $90 \%$ hal yang sudah disampaikan adalah dengan melihat, mendengar, mengatakan dan melakukan. Semua itu merupakan gabungan dalam proses belajar. 4).Menyediakan cara pendekatan yang lebih kreatif untuk mengajar. (Anaknto 2014:5). Maka dapat disimpulkan bahwa penggunaan Multimedia selain memberikan motivasi kepada pebelajar juga dapat merangsang pebelajar mengingat apa yang sudah dipelajari selain memberikan rangsangan belajar baru. Multimedia yang baik juga akan mengaktifkan pebelajar dalam memberikan tanggapan, umpan balik dan juga mendorong pebelajar untuk melakukan praktek-praktek dengan benar. 


\section{METODE}

Penelitian ini dilaksanakan di Sekolah Minggu BNKP Ressort 48 dan Ressor 42 dengan Metode penelitian yang digunakan adalah metode penelitian dan pengembangan (research and development). Metode penelitian dan pengembangan adalah metode penelitian yang digunakan untuk menghasilkan produk tertentu, dan menguji keefektifan produk tersebut. Peneliti melakukan penelitian dan pengembangan sumber belajar berbasis multimedia. Proses pelaksanaan pengembangan sumber belajar berbasis multimedia ini dilakukan secara bertahap.

a. Tahap pertama dalam kegiatan pengembangan ini adalah melakukan analisis kebutuhan.

b. Tingkat kelayakan sumber belajar diketahui melalui validasi oleh ahli materi, validasi oleh ahli media, validasi oleh guru Sekolah Minggu dan uji coba penggunaan oleh Guru dan anak- anak Sekolah Minggu.

Analisis data dalam penelitian ini menggunakan analisis deskriptif kuantitatif, semua data yang terkumpul dianalisis dengan teknik statistik deskriptif yang secara kuantitatif dipisahkan menurut kategori untuk mempertajam penilaian dalam menarik kesimpulan. Data kualitatif yang berupa pernyataan sangat kurang baik, kurang baik, sedang, baik dan sangat baik diubah menjadi data kuantitatif dengan skala nilai 1 sampai 5 .

Untuk mengetahui nilai keefektifan Pemanfaatan sumber belajar berbasis Multimedia dalam pembelajaran yang dieksperimenkan, dapat digunakan dengan cara membandingkan efektifitas yang diperoleh dengan efektifitas ideal (Sugiyono, 2011: 415-418)

$$
\begin{gathered}
X=\frac{\text { skor kefektifan yang diperoleh }}{\text { skor } k \text { efektifan ideal }} \\
\times 100 \%
\end{gathered}
$$

\section{HASIL PENELITIAN}

\begin{tabular}{|l|l|c|c|c|}
\hline No. & $\begin{array}{l}\text { Evaluasi } \\
\text { Uji coba } \\
\text { lapangan }\end{array}$ & $\begin{array}{c}\text { Juml } \\
\text { ah } \\
\text { Skor }\end{array}$ & $\begin{array}{c}\text { Rata- } \\
\text { rata } \\
\%\end{array}$ & $\begin{array}{c}\text { Krite } \\
\text { ria }\end{array}$ \\
\hline 1. & $\begin{array}{l}\text { Guru } \\
\text { Sekolah } \\
\text { Minggu }\end{array}$ & 3568 & $95 \%$ & $\begin{array}{l}\text { Sang } \\
\text { at } \\
\text { Baik }\end{array}$ \\
\hline
\end{tabular}

Uji Hipotesis:

Ha : Efektifitas Pemanfaatan Sumber Belajar Berbasis Multimedia Dalam Pembelajaran Sekolah Minggu BNKP Paling Tinggi $80 \%$ dari kriteria yang diharapkan

Ho : Efektifitas Pemanfaatan Sumber Belajar Berbasis Multimedia Dalam Pembelajaran Sekolah Minggu BNKP lebih Tinggi $80 \%$ Dari kriteria yang diharapkan.

Jadi Efektifitas Pemanfaatan Sumber Belajar Berbasis Multimedia Dalam Pembelajaran Sekolah Minggu BNKP Paling Tinggi $80 \%$ dari Kriteria yang diharapkan kurang tepat bahkan lebih dari apa yang diduga sebelumnya.

\section{PEMBAHASAN}

Dari hasil pengolahan data penelitian yang dilakukan, pembelajaran dengan pemanfaatan Sumber Belajar Berbasis Multimedia di Sekolah Minggu BNKP lebih Efektif dibandingkan dengan pembelajaran sebelum menggunakan multimedia. Seperti halnya pembelajaran dengan tanpa menggunakan media artinya guru sekolah minggu bercerita secara verbal, guru tidak berinteraksi langsung pada sumber informasi dan pembelajaran lebih banyak didominasi oleh guru yang menyajikan informasi secara linier atau satu arah, keadaan ini terjadi menempatkan guru menggunakan kontrol pembelajaran dengan aktif, sementara anak-anak relative 
pasif menerima dan mengikuti apa yang disampaikan guru. Pada pelaksanaan pembelajaran tanpa media, guru menyampaikan materi secara terstruktur dengan harapan materi pelajaran yang disampaikan dapat dikuasai dengan baik dengan terfokus kepada kemampuan akademik. Sedangkan pada pemanfaatan multimedia tidak hanya fokus pada kemampuan akademik melainkan seluruh kepribadian anakanak terlibat aktif dalam pembelajaran. Hal ini telah terbukti melalui pelaksanaan pembelajaran di sekolah minggu, dimana hasilnya anak- anak sekolah minggu menunjukkan sikap kreatif, kemampuan berpikir semakin meningkat dan tentu penguasaan cerita semakin baik.

\section{SIMPULAN}

Berdasarkan teori dan hasil penelitian maka dapat disimpulkan bahwa: Penggunaan sumber elajar berbasis Multimedia dalam pembelajaran memberi banyak model mental yang lebih akurat dan efektif. Multimedia salah satu sarana belajar yang bisa melibatkan seluruh panca indera anak-anak dalam belajar sehingga pembelajaran yang dilaksanakan akan diminati dan dikuasai.

Sumber belajar berbasis Multimedia layak digunakan pada pembelajaran sekolah minggu, sebagaimana hasil yang ditunjukkan oleh data penelitian yang telah dianalisis oleh peneliti. keuntungan baik bagi guru maupun anak-anak sekolah minggu yaitu meningkatkan efektifitas dan efisiensi pelaksanaan pembelajaran sehingga pembelajaran yang dimaksud dapat mencapai tujuan sebagaimana diharapkan. Kehadiran sumber belajar berbasis Multimedia bermanfaat untuk memecahkan permasalahan yang dihadapi termasuk dalam proses pembelajaran di sekolah minggu, seperti masalah kehadiran anak-anak sekolah minggu, masalah perhatian terhadap pemberitaan Firman, dan kemudahan untuk mendengar dan menyampaikan Firman Tuhan.

Kehadiran sumber belajar berbasis Multimedia dapat memberi pemahaman bahwa posisi guru bukan lagi sebagai satu- satunya sumber belajar, tetapi sebagai fasilitator.

Multimedia yang dirancang dengan baik, membantu anak-anak membangun karakter dan kemampuan berpikir. 


\section{DAFTAR PUSTAKA}

Asyhar, Rayandra dkk. 2012. Kreatif mengembangkan

Media Pembelajaran. Referensi Jakarta.

Felder, R.M. dan R. Brent, Effective Strategies for Cooperative Learning" Jounal of Cooperation \& Collaboration in College Teaching 10, no. 2 pp 63-69.2001.

Kadarmanto. 2005. Tuntunlah Ke Jalan Yang Benar. BPK Gunung Mulia. Jakarta.

Kristianto, Paulus. 2006. Prinsip dan Praktik Pendidikan Agama Kristen. ANDI. Yogyakarta.

Lie Paulus. 2003. Mereformasi Sekolah Minggu. ANDI. Yogyakarta. Pembelajaran Sebuah Pendekatan Baru. Gaung Persada (GP) Press. Jakarta.

Munir. 2001. Pengantar, Fasilitas Penggunaan Komputer. Direktorat Teknologi Informasi dan Komunikasi UPI. Bandung.

Munir. (2009). Pembelajaran Jarak Jauh: Berbasis Teknologi Informasi dan Komunikasi, Bandung, CV. ALVABETA.

Setiawani. 2004. Menerobos Dunia Anak. Bandung : Yayasan Kalam Hidup.

Siswanto Igrea. 2014. 50 Kreasi Asyik Untuk Mengajarkan Firman Tuhan Secara Menarik Kepada Anak. ANDI. Yogyakarta. 